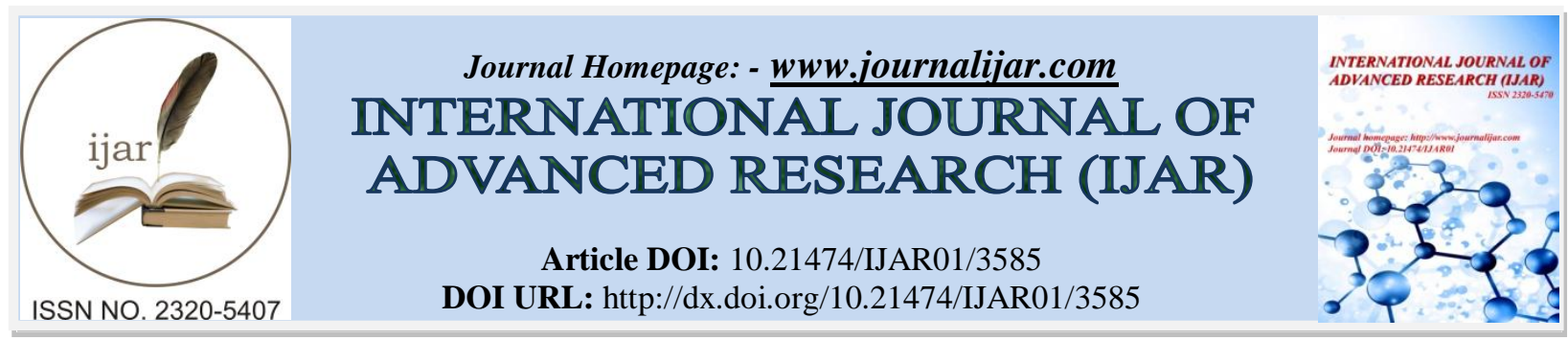

RESEARCH ARTICLE

\title{
UTILIZATION OF FLOURS OF FOX NUTS AND WATER CHESTNUTS FOR PREPARATION OF PUA.
}

Neda Shamim $^{1^{*}}$ and Virginia Paul ${ }^{2}$

1. Research Scholar, Department of Foods, Nutrition and Public Health, ECHS, SHUATS, Allahabad.

2. Associate Professor, Department of Foods, Nutrition and Public Health, ECHS, SHUATS, Allahabad.

\section{Manuscript Info}

Manuscript History

Received: 04 January 2017

Final Accepted: 08 February 2017

Published: March 2017

Key words:-

Water chestnuts, Fox nuts, Product development, Nine point hedonic scale.

\section{Abstract}

Background: The idea of incorporating of flour being nutritionally rich fulfills the requirement of healthy snacks. As protein and vitamin deficiencies are very common in India, efforts are underway to enrich cereals, in supplements with, vegetable used in effective manner.

Aim: The objective of the study is to evaluate organoleptic attributes, nutritive value and cost of prepared food product.

Methods: The products were organoleptically evaluated for the colour and appearance, body and texture, taste and flavour and over all acceptability using Nine point Hedonic scale. Nutritional composition was determined using the standardized AOAC (2005) methods.

Statistical analysis: The data were statistically analyzed by using analysis of variance technique, critical difference test.

Results: On the basis of findings, it was observed that in context with organoleptic attributes, treatment $T_{2}$ was best as compared to control and other treatments, however all the treatments were found acceptable. Nutrient composition of Pua treatment $\mathrm{T}_{2}$ was rich in Protein $(7 \mathrm{~g} / 100 \mathrm{~g})$, Carbohydrate $(66 \mathrm{~g} / 100 \mathrm{~g})$ and Iron content $(2 \mathrm{mg} / 100 \mathrm{~g})$. Average cost of the Pua per $100 \mathrm{~g}$ of raw ingredients was Rs. 13.25 for $\mathrm{T}_{0}$ (control), Rs. 17.25 for $\mathrm{T}_{1}$, Rs. 19.25 for $\mathrm{T}_{2}$ and Rs. 21.25 for $\mathrm{T}_{3}$.

Conclusion: Incorporation of flours of Fox nuts and Water Chestnuts in Pua is well acceptable and can be used for the development of food product.

Copy Right, IJAR, 2017,. All rights reserved.

\section{Introduction:-}

The idea of incorporating of flour being nutritionally rich fulfills the requirement of healthy snacks. As protein and vitamin deficiencies are very common in India, efforts are underway to enrich cereals, in supplements with, vegetable used in effective manner (Pragati and Paul, 2010).

Fox nut or Gorgon nut, commonly known as Makhana, Popped Makhana is used in preparation of a number of delicious and rich sweet dishes, pudding and milk based sweets. Fox nuts are low in calories, fat (saturated fats) and sodium and high in magnesium, potassium, phosphorus and fiber. They have antioxidants properties and good food for diabetics, arthritis, kidney diseases, constipation, diarrhea, cancer, anemia, heart problems. It improves appetite, moisture level in body tissues and prevents the inflammations in the body. It helps the body to remove the waste and thus prevent the accumulation of toxins. It also contains useful medicinal properties (Das et al., 2006).

Corresponding Author:- Neda Shamim.

Address:- Research Scholar, Department of Foods, Nutrition and Public Health, ECHS, SHUATS, Allahabad. 
Water chestnut (Trapa Bisinosa Roxburg) commonly known as "Singhara", is an annual aquatic warm season crop. They are almost fatless and are therefore, a healthy food option. Ground water chestnut powder mixed with water can relive cough. Boiling water chestnuts in water makes the best drink for measles patients and is appropriate for all measles patients from the third day till the ninth day of the cycle. Is helps to speed up the measles cycle. They are good sources of calorie, carbohydrate, dietary fiber, vitamin B6 and also contain fair amount of calcium, potassium, iron and zinc. Water chestnut used for many therapeutic purposes e.g. for jaundice, measles, cough and summer heat etc (Masrizal et al., 1997).

The study was carried out to develop pua by incorporation of flour of fox nuts and water chestnuts, to evaluate the organoleptic acceptability of the prepared product and to determine the nutrient composition of the prepared product.

\section{Methodology:-}

The present study was conducted in Sam Higginbottom University of Agriculture Technology and Sciences, Allahabad.

\section{Procurement of Raw Materials:-}

The required materials i.e. Fox nuts and water chestnuts, Bengal gram flour, sugar, cardamom, coconut powder, coco powder, refined oil and vegetable etc were collected from local market of Allahabad city.

\section{Preparation of fox nuts and water chestnuts flour:-}

Fox nuts and water chestnut was Cleaned, after that Sun drying was done for one day, then fox nuts and water chestnuts was Grinned, then Fox nuts and water chestnuts flour was Packed (Airtight tin containers or polythene bags) and Storage (At ambient temperature in dry place) Srivastava and Kumar (2009).

\section{Control and three experimental treatments were prepared as follows:-}

$\mathbf{T}_{\mathbf{0}}$ (Control): In this, the standardized recipe was followed to prepare the products without any incorporation fox nuts flour.

$\mathbf{T}_{\mathbf{1}}(\mathbf{9 0 \%}, \mathbf{1 0 \%})$ : In this treatment, 90 percent Water chestnut flour and 10 percent Fox nut flour to prepare products. $\mathbf{T}_{\mathbf{2}}(\mathbf{8 5} \%, \mathbf{1 5 \%})$ : In this treatment, 85 percent Water chestnut flour and 15 percent Fox nut flour to prepare products. $\mathbf{T}_{\mathbf{3}}(\mathbf{8 0} \%, \mathbf{1 0 \%})$ : In this treatment, $80 \%$ Water chestnut flour and 20 percent Fox nut flour to prepare products.

Replications: All the treatments of the four products respectively were replicated four times to get average values.

\section{Organoleptic Evaluation:-}

Sensory evaluation of the Pua for their acceptability was done by a panel of judges. Colour, Texture, Flavor, Taste and Overall acceptability were evaluated using the nine point hedonic scale based score card. (Srilakshmi, 2003).

\section{Calculation of Nutritive Value of Prepared Products:-}

The nutrient composition of the value added product were determined by AOAC method (2005) to estimate the moisture, total ash, protein, fat, carbohydrate, iron and calcium content.

\section{Cost of prepared products:-}

The cost of the products was calculated on the basis of price of raw ingredients at rupees $/ \mathrm{kg}$.

Nutrient/100gm of product:- $\underline{\text { Ingredient used }(\mathrm{g} \text {. }) \times \text { nutritive value of ingredient }}$

$$
100
$$

\section{Statistical analysis of the Products:-}

Data is ascertained from the experiment was statistical analyzed using analysis of variance technique and critical difference test (Fisher, 1995). 
Results and Discussion:-

Average Sensory Attributes Of Value Added Pua.

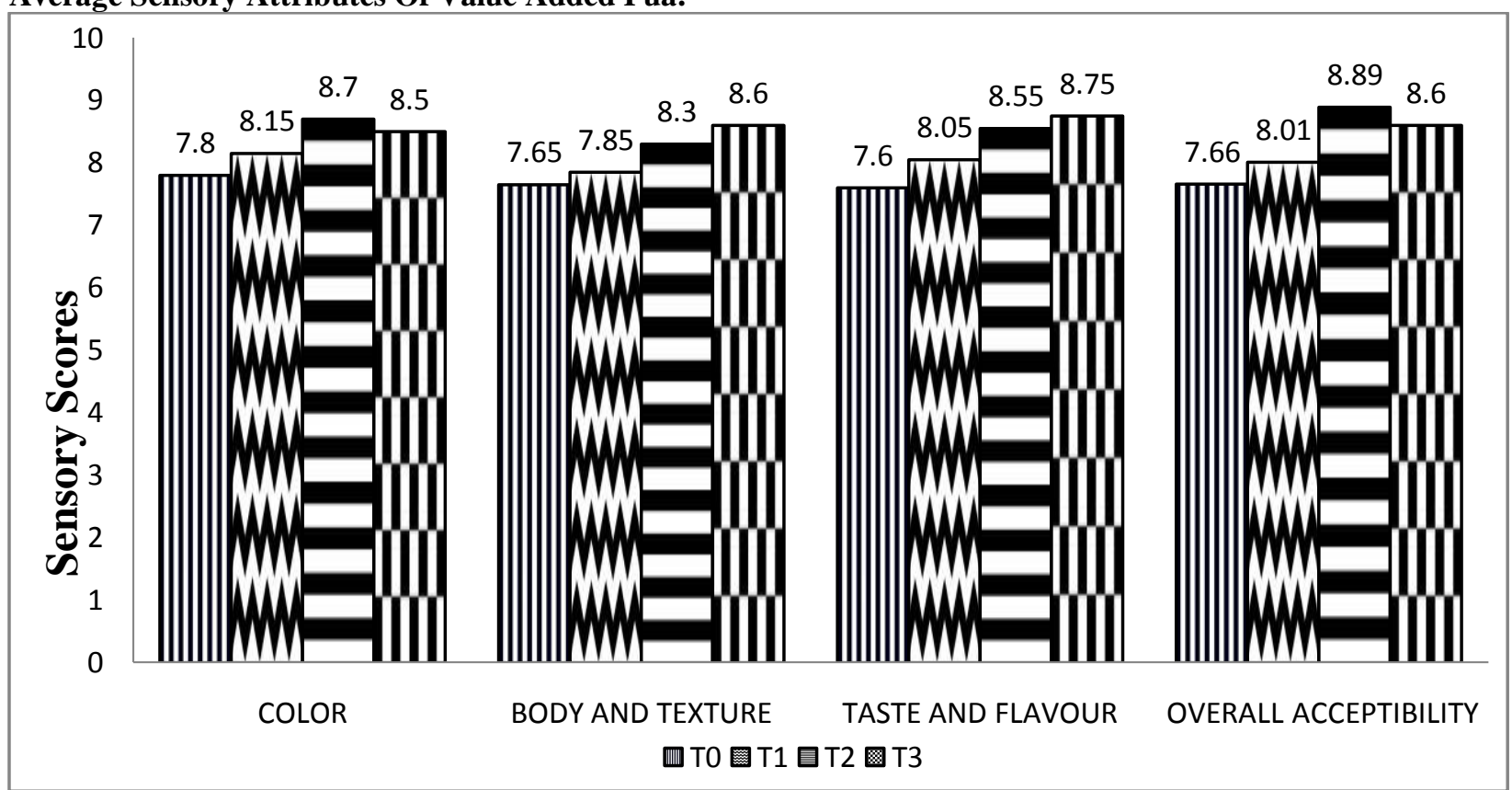

Figure 1:- Average Sensory Score for Different Treatments of Pua

Figure 1 shows the mean scores of Pua in relation to overall acceptability indicates that the treatment $\mathrm{T}_{2}(8.89)$ has the highest score followed by $\mathrm{T}_{3}(8.60), \mathrm{T}_{1}(8.01)$ and $\mathrm{T}_{0}$ (7.66) respectively, making quite obvious that the incorporation of 85 percent water chestnut flour and 15 percent fox nut flour showed the best result for overall acceptability. Therefore, it can be calculated that there was significant difference between the treatments for overall acceptability of Pua. All treatments were acceptable on 9 point Hedonic scale and liked very much by the panel of judges.

Kumari and Paul (2012) studied the incorporation of coarse grain bajra flour and chick pea flour into the traditional recipe Pua. The result shown that the treatments $\mathrm{T}_{3}$ were most acceptable among all the treatment they obtained a mean score of 6.92, 7.6, 7.68 and 7.42 for colour, body and texture, taste and flavour and overall acceptability.

Nutrient Composition Of The Product:-

Table 1:- Mean nutrient composition of the Pua developed by incorporation of flours of water chestnuts and fox nuts (per $100 \mathrm{~g}$ ).

\begin{tabular}{|c|c|c|c|c|c|c|c|c|}
\hline \multicolumn{2}{|c|}{$\begin{array}{l}\text { Product/ } \\
\text { Treatments }\end{array}$} & $\begin{array}{l}\text { Moisture } \\
(\mathrm{g})\end{array}$ & Ash (g) & Fat $(\mathrm{g})$ & Protein $(\mathrm{g})$ & $\mathrm{CHO}(\mathrm{g})$ & $\begin{array}{l}\text { Calcium } \\
(\mathrm{mg})\end{array}$ & Iron (mg) \\
\hline Pua & $\mathrm{T}_{0}$ & $12.64 \pm 1.12$ & $22.07 \pm 0.43$ & $15.85 \pm 0.92$ & $4.12 \pm 0.08$ & $60.23 \pm 0.34$ & $30.28 \pm 3.24$ & $1.16 \pm 0.03$ \\
\hline & $\mathrm{T}_{2}$ & $8.20 \pm 0.28$ & $22.36 \pm 0.39$ & $14.37 \pm 0.51$ & $7 \pm 0.19$ & $66.10 \pm 0.87$ & $28.11 \pm 2.19$ & $1.64 \pm .43$ \\
\hline
\end{tabular}

A wide range of variation was observed in the nutrient content of the product and treatment. $T_{2}$ was found to be the best treatment among all the treatments. Therefore along with $\mathrm{T}_{0}$, nutrient composition of $\mathrm{T}_{2}$ was determined. Results from the table 2 shows that the moisture content was highest in pua $\mathrm{T}_{0}(13 \mathrm{~g} / 100 \mathrm{~g})$, Ash content was highest in $T_{2}(23 \mathrm{~g} / 100 \mathrm{~g})$, Fat content was $\mathrm{T}_{0}(16 \mathrm{~g} / 100 \mathrm{~g})$, protein content was $\mathrm{T}_{2}(7 \mathrm{~g} / 100 \mathrm{~g})$, in carbohydrate content was $\mathrm{T}_{2}$ $(66 / 100 \mathrm{~g})$, calcium content was $\mathrm{T}_{0}(30 \mathrm{mg} / 100 \mathrm{mg})$ and iron content was highest in $\mathrm{T}_{2}(1.64)$

The result is supported by the findings of Singh $\boldsymbol{e t}$ al., (2009). The Pua is prepared with the incorporation of bajra flour, maize flour in whole wheat flour. Protein content increased as the incorporation level of bajra and maize flour increased. Fat content was lowest in $\mathrm{T}_{0}(51.07 \mathrm{~g})$, followed by $\mathrm{T}_{1}, \mathrm{~T}_{2}, \mathrm{~T}_{3}$. Calcium content was highest in $\mathrm{T}_{2}(112.45$ $\mathrm{mg}$ ), followed by $\mathrm{T}_{3} \mathrm{~T}_{2}, \mathrm{~T}_{1}$ and $\mathrm{T}_{0}$ and carbohydrate content as the amount of bajra and maize flour increased. Iron 
content was found highest in $T_{0}(12 \mathrm{mg})$, followed by $\mathrm{T}_{1}, \mathrm{~T}_{2}, \mathrm{~T}_{3}$. Moisture content was high in $\mathrm{T}_{3}$ (13.45), followed by $\mathrm{T}_{2,} \mathrm{~T}_{1}$ and $\mathrm{T}_{0}$.

\section{Cost Of Raw Ingredients:-}

The cost has been calculated on the basis of prevailing price of raw materials. It is evident that the cost of Pua $\mathrm{T}_{1}$ was lowest i.e. (17.25 Rs/100g) as compared to experimental pua samples, $\mathrm{T}_{2}(19.25 \mathrm{Rs} / 100 \mathrm{~g})$ and $\mathrm{T}_{3}(21.25$ $\mathrm{Rs} / 100 \mathrm{~g})$. The cost of the developed product is increasing due to incorporation of water chestnut and fox nut flour at different levels.

\section{Conclusion:-}

It is concluded that incorporation of flour of water chestnuts and fox nuts in product like Pua is well acceptable. In pua $\mathrm{T}_{2}$ (85percent water chestnuts flour +15 percentfox nuts flour) was the best on all sensory parameter. For Pua treatment $\mathrm{T}_{2}$ (85percent water chestnut and 15percent fox nut flour) was rich in protein $(7 \mathrm{~g} / 100 \mathrm{~g})$ and carbohydrate content $(66 \mathrm{~g} / 100 \mathrm{~g})$. The lowest cost of the developed food product per $100 \mathrm{~g}$ of raw ingredients was Rs-13.25 for Pua of the treatment $\mathrm{T}_{1}$.

\section{References:-}

1. AOAC (2005). Official methods of analysis of the association of official analytical chemists. $18^{\text {th }}$ Ed.

2. Das S., Der P., Chaudhari UR., Maulik N. and Das DK (2006). The Effect of Euryale Ferox (Makhana), an Herb of Aquatic Origin, on Myocardial Ischemic Reperfusion Injury. Molecular and Cellular Biochemistry. 289(2): 55-63.

3. Fisher R.A. (1995). Statistical Method for Research Workers. Edinburgh: Oliver and Boyd; 14: 148- 149.

4. Kumari S. and Paul V. (2012). Value addition of traditional recipe for the preparation of snacks. Master in science in food nutrition and dietetics, Ethelind School of Home Science. pp: 30-60.

5. Masrizal M.A., Girand D.W. and Driskell J.A. (1997). Retention of Vitamin C and iron or Beta carotene in vegetables prepared using different cooking method. Journal of food quality. 20(5):403-418.

6. Singh N., Prasad R., Neerubala, Sheikh S., Masih S. and Ramteke P.W. (2009). Formulation of value added snacks by an admixture of flour. Master in Science in Food Nutrition and Dietetics, Ethelind School of Home Science. pp: 30-60.

7. Srilakshmi, B. (2003). Food science $4^{\text {th }}$ Ed. New age international (P) Ltd., New Delhi.170-174.

8. Srivastava R.P. and Kumar S. (2009). Fruits and Vegetable drying, dehydration and concentration. $3^{\text {rd }}$ Edition, Published by International book distributing company, Lucknow. 2009, 14.

9. Pragati and Paul V. (2010). Development of value added snacks by admixture of mushroom flour, wheat flour and soy flour. Institute of Science and Technology, Allahabad; 80-97. 